\title{
Delineating FOXG1 syndrome
}

\section{From congenital microcephaly to hyperkinetic encephalopathy}

Nancy Vegas, MD, Mara Cavallin, MD, Camille Maillard, MD, Nathalie Boddaert, MD, PhD, Joseph Toulouse, MD, Elise Schaefer, MD, Tally Lerman-Sagie, MD, Dorit Lev, MD, Barth Magalie, MD, Sébastien Moutton, MD, Eric Haan, MD, Bertrand Isidor, MD, Delphine Heron, MD, Mathieu Milh, MD, PhD, Stéphane Rondeau, MD, Caroline Michot, MD, PhD, Stephanie Valence, MD, Sabrina Wagner, MD, Marie Hully, MD, Cyril Mignot, MD, Alice Masurel, MD, Alexandre Datta, MD, Sylvie Odent, MD, PhD, Mathilde Nizon, MD, Leila Lazaro, MD, Marie Vincent, MD, Benjamin Cogné, MD, Anne Marie Guerrot, MD, Stéphanie Arpin, MD, Jean Michel Pedespan, MD, Isabelle Caubel, MD, Benedicte Pontier, MD, PhD, Baptiste Troude, MD, Francois Rivier, MD, PhD, Christophe Philippe, MD, PhD, Thierry Bienvenu, MD, PhD, Marie-Aude Spitz, MD, Amandine Bery, PhD, and Nadia Bahi-Buisson, MD, PhD

Neurol Genet 2018;4:e281. doi:10.1212/NXG.0000000000000281

\section{Abstract}

\section{Objective}

To provide new insights into the FOXG1-related clinical and imaging phenotypes and refine the phenotype-genotype correlation in FOXG1 syndrome.

\section{Methods}

We analyzed the clinical and imaging phenotypes of a cohort of 45 patients with a pathogenic or likely pathogenic FOXG1 variant and performed phenotype-genotype correlations.

\section{Results}

A total of 37 FOXG1 different heterozygous mutations were identified, of which 18 are novel. We described a broad spectrum of neurodevelopmental phenotypes, characterized by severe postnatal microcephaly and developmental delay accompanied by a hyperkinetic movement disorder, stereotypes and sleep disorders, and epileptic seizures. Our data highlighted 3 patterns of gyration, including frontal pachygyria in younger patients $(26.7 \%)$, moderate simplified gyration (24.4\%) and mildly simplified or normal gyration (48.9\%), corpus callosum hypogenesis mostly in its frontal part, combined with moderate-to-severe myelination delay that improved and normalized with age. Frameshift and nonsense mutations in the $\mathrm{N}$-terminus of FOXG1, which are the most common mutation types, show the most severe clinical features and MRI anomalies. However, patients with recurrent frameshift mutations c.460dupG and c.256dupC had variable clinical and imaging presentations.

\section{Conclusions}

These findings have implications for genetic counseling, providing evidence that $\mathrm{N}$-terminal mutations and large deletions lead to more severe FOXG1 syndrome, although genotypephenotype correlations are not necessarily straightforward in recurrent mutations. Together, these analyses support the view that FOXG1 syndrome is a specific disorder characterized by frontal pachygyria and delayed myelination in its most severe form and hypogenetic corpus callosum in its milder form.

\author{
Correspondence \\ Pr. Bahi-Buisson \\ nadia.bahi-buisson@aphp.fr
}




\section{Glossary}

FBD $=$ forkhead binding domain.

Mutations in the FOXG1 gene have been shown to cause a rare neurodevelopmental disorder. Initially described as a "congenital variant of Rett syndrome," ${ }^{1,2}$ subsequent reports allowed delineation of the FOXG1 syndrome, which is now considered a distinct clinical entity. ${ }^{3-7}$

To date, more than 90 individuals with FOXG1 mutations have been described, mostly within small case series. ${ }^{5,7}$ The disorder comprises a complex constellation of clinical features, including severe postnatal microcephaly, deficient social reciprocity, combined stereotypies and dyskinesias, epilepsy, poor sleep patterns, and unexplained episodes of crying. ${ }^{3}$ In parallel to these clinical criteria, the importance of brain MRI features has been emphasized. ${ }^{1,3,8}$ However, the spectrum of MRI features in FOXG1 syndrome is yet to be fully defined.

FOXG1 encodes a transcription factor containing a highly conserved domain spanning from the forkhead binding domain (FBD) to the $\mathrm{C}$-terminus and a variable $\mathrm{N}$-terminus. ${ }^{9}$ FOXG1 mutations include frameshifts, deletions, and point mutations. ${ }^{7,10}$ A recent study suggests that more severe phenotypes are associated with truncating FOXG1 variants in the $\mathrm{N}$-terminus and the FBD and milder phenotypes with missense variants in the FBD. The most significant differences were related to motor and speech development, while only borderline differences were found concerning corpus callosum anomalies, delayed myelination, and microcephaly. ${ }^{7}$

In light of these recent findings, the aim of this study was to provide a comprehensive overview of FOXG1-related clinical and imaging phenotypes by thorough analysis of a cohort of 45 clinically well-characterized patients with FOXG1 mutation and refine the phenotype-genotype correlation in FOXG1 syndrome.

\section{Methods}

We recruited patients with pathogenic or likely pathogenic FOXG1 mutations from different cohorts through a large national and international network. Genetic testing was performed by array comparative genomic hybridization (CGH) (5/45), Sanger sequencing (31/45), targeted panel high-throughput sequencing (4/45), and whole-exome sequencing (4/45).

\section{Standard protocol approvals, registrations, and patient consents}

The study was approved by the ethics committee of the University Hospital of Necker Enfants Malades, Paris, France and the relevant local institutional review boards. Parental written informed consent was obtained for all affected patients.

All patients were personally known to at least 1 of the coauthors and were reexamined for the purpose of the study.
Five patients had been reported previously and were reassessed for the study. ${ }^{8,11,12}$ Standardized clinical information was recorded. Movement disorders were characterized in person by investigators and classified according to established criteria. ${ }^{13}$ Epileptic seizures were classified according to the recommendations of the Commission on Classification and Terminology of the International League Against Epilepsy.

In addition, for patients filmed, we obtained additional authorization for disclosure of any recognizable persons in videos.

The genetic testings were performed in accordance with the respective national ethics guidelines and approved by the local authorities in the participating study centers.

\section{MRI studies}

As the MRI studies were performed over a period of 10 years at many different imaging centers and on many different types of MR scanners, the imaging techniques that were used differed substantially, although a majority had at least axial and sagittal T1-weighted and axial T2-weighted and fluidattenuated inversion recovery (FLAIR) sequences. Imaging assessment was based on agreement between 2 investigators (N.B. and N.B.-B.) who reviewed the images. Each made initial evaluations independently, and any disagreements regarding the final conclusion were resolved by consensus.

\section{Statistical analysis}

All statistical analyses were performed in GraphPad Prism version 6.00. Data are described as mean \pm SEM. Differences were evaluated using the 2-way analysis of variance with multiple comparison tests.

The study was approved by the ethics committee of the University Hospital of Necker Enfants Malades, Paris, France and the relevant local institutional review boards. Parental written informed consent was obtained for all affected patients.

\section{Results}

Our cohort totaled 45 patients with FOXG1 mutations, 22 males and 23 females ranging in age from 19 months to 42 years (median: 5.73 years) at the time of evaluation (table e-1 links.lww.com/NXG/A97).

A total of 37 FOXG1 different heterozygous mutations were identified, of which 18 are novel. They comprised 32 small intragenic mutations and 5 large deletions of the whole FOXG1 locus. All mutations were de novo, except 1 reported previously as a germinal mosaic. ${ }^{12}$ Point mutations were mostly frameshifts (14/32; 43.75\%) and missense mutations (12/32; 37.5\%), with a small number of nonsense $(4 / 32 ; 12.5 \%)$ and in-frame 
mutations $(2 / 32 ; 6.25 \%)$ (figure $1, A$ and B). Three recurrent mutations, c.460dupG, c.256dupC, and c.256delC, were identified.

\section{Clinical presentation in patients with FOXG1 mutations}

Patients first came to medical attention at a median age of 3 months (birth to 20 months) because of developmental delay and microcephaly $(15 / 45 ; 33.3 \%)$ or with lack of eye contact, or strabismus $(16 / 45 ; 35.6 \%)$. Epileptic seizures or movement disorder were less common $(4 / 45 ;<10 \%)$. In 5 cases (11.1\%), brain anomalies were diagnosed prenatally.

At birth, a majority of patients had normal body measurements and low normal birth head size (38/43; 88.4\%). Severe postnatal microcephaly ( -4 to $-6 \mathrm{SD})$ became apparent after the age of 1 month.

At the age of the last evaluation (median: 5 years; 19 months to 42 years), all patients had profound developmental delay, with permanent esotropia (38/42; 90.7\%) (video 1 links.lww.com/ NXG/A99). Hand use was severely limited to involuntary gross manipulation $(13 / 44 ; 29.5 \%)$ (video 2 links.lww.com/NXG/ A100). On examination, a complex movement disorder was the most prominent feature characterized by generalized hyperkinetic and dyskinetic movements that was present at rest and worsened with attempts to movement (videos 3 and 4 links. lww.com/NXG/A101 and links.lww.com/NXG/A102), with orolingual dyskinesias $(12 / 33 ; 36.4 \%)$ (video 5 links.lww.com/ NXG/A103); 34 of 43 patients (79.1\%) also showed hand stereotypies, consisting of hand pressing/wringing or hand mouthing (videos 6 and 7 links.lww.com/NXG/A104, links. lww.com/NXG/A105), which are unusual in the context of dyskinetic movement disorders. Thirty-two of 44 patients (72. $7 \%)$ had feeding difficulties associated with gastroesophageal reflux (videos 8 and 9 links.lww.com/NXG/A106 and links. lww.com/NXG/A107). Sleep problems were frequent (27/42; $64.3 \%)$ and included multiple nocturnal awakenings or difficulties in falling asleep with irritability and inconsolable crying or inappropriate laughing $(25 / 40 ; 62.5 \%)$. Seizures were documented in $77.8 \%(35 / 45)$ of patients and occurred at a mean age of 2.5 years (range: 2 days to 12 years). Generalized tonic or tonic-clonic seizures were the most frequent seizure type $(21 / 35 ; 60 \%)$. Of the 35 patients, 17 (48.6\%) developed refractory epilepsy with multiple seizure types and 5 (14.3\%) experienced at least 1 episode of status epilepticus (table 1).

Because, FOXG1 mutations had been previously associated with congenital Rett variant, we examined the prevalence of congenital Rett-supportive manifestations. Overall, 2 of 21 females (9.5\%) and 1 of 21 males (4.76\%) fulfilled the diagnostic criteria for Rett syndrome ${ }^{14}$ (table e-2 links.lww.com/NXG/A98).

Figure 1 Schematic representation of FOXG1 gene, protein domain structure, and positions of FOXG1 mutations

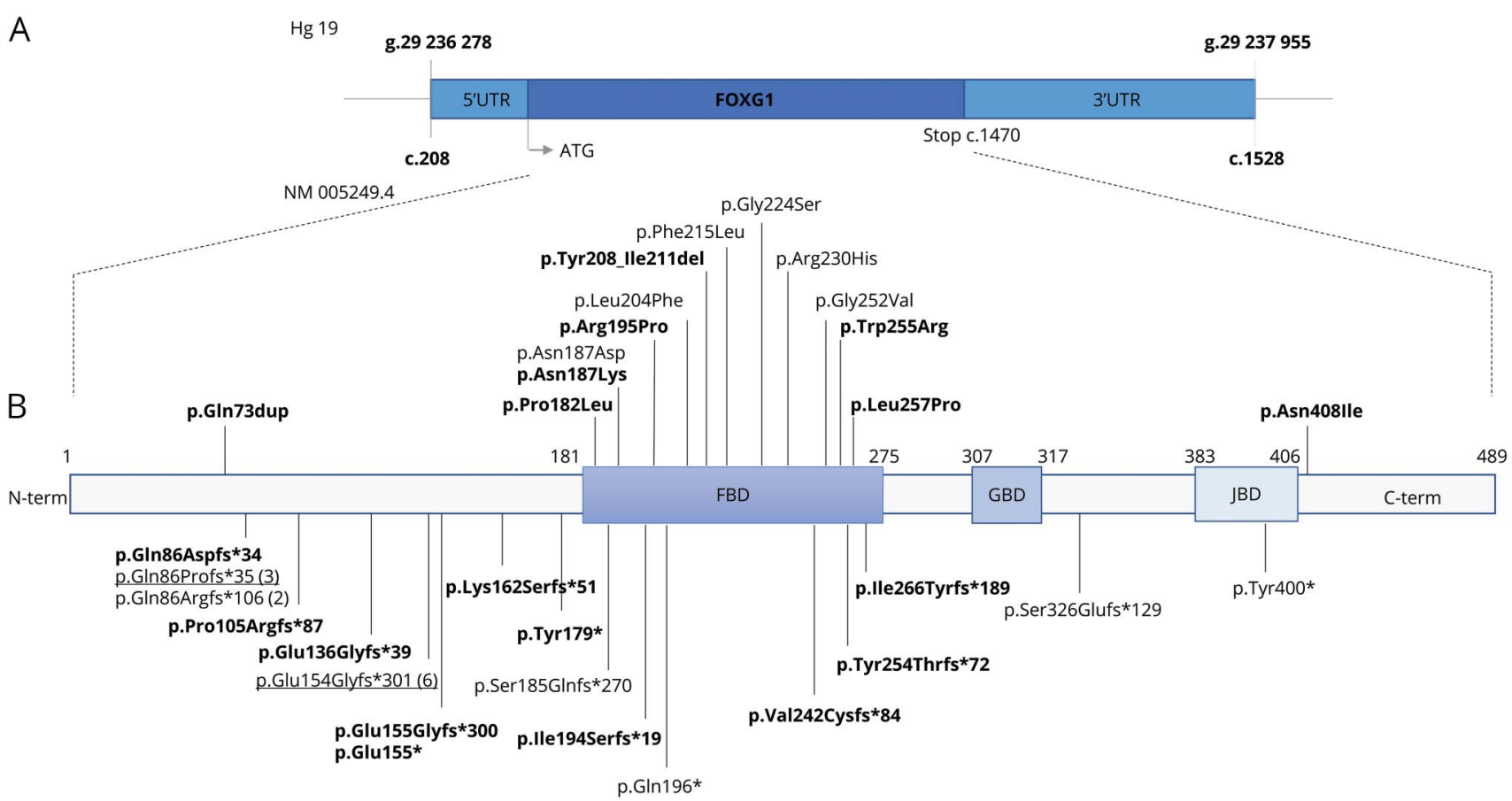

(A) Schematic representation of FOXG1 gene and (B) FOXG1 protein domain structure and positions of the variations identified: N-terminal domain; FBD domain (forkhead DNA binding domain, amino acids 181-275), GBD domain (Groucho binding domain, amino acids 307-317), JBD domain (JARID1B binding domain, amino acids 383-406), and C-terminal domain are indicated. Mutations are located all along the FOXG1 gene, within different protein domains. Missense mutations are predominantly located in the FBD (91.7\%), whereas frameshift mutations are more prominent in the $\mathrm{N}$-terminal domain (57.1\%). The novel variants described in this article are highlighted in bold and the recurrent variants are underlined with the corresponding number of recurrences indicated in brackets. FBD = forkhead binding domain; GBD = Groucho binding domain; JBD = JARID1B binding domain. 
Table 1 Individual data on epilepsy and MRI pattern on 45 patients with de novo FOXG1 mutations/deletions

\begin{tabular}{|c|c|c|c|c|c|c|c|}
\hline Patient/sex & $\begin{array}{l}\text { Age at last } \\
\text { follow-up }\end{array}$ & Mutation & Epilepsy & $\begin{array}{l}\text { Age at } \\
\text { seizure onset }\end{array}$ & Seizure history & $\begin{array}{l}\text { Age at } \\
\text { MRI }\end{array}$ & MRI Pattern \\
\hline Tel02/M & 4 y 6 mo & p.Gln73dup & Yes & $1 \mathrm{y}$ & Brief GTS (every 2 wk) under AED & 2 y 8 mo & $\begin{array}{l}\text { Moderate SIMP with cortical atrophy, severe } \\
\text { myelination delay, hypoplastic CC, and } \\
\text { normal cerebellum }\end{array}$ \\
\hline Trs1/F & 3 y $6 \mathrm{~m}$ & p.Gln86Prosfs*35 & Yes & $6 \mathrm{mo}$ & $\begin{array}{l}\text { IS then evolved to GTS ( } 1 \text { SE at } 2 \text { y } 6 \text { m) } \\
\text { followed by GTCS, drug resistant }\end{array}$ & $11 \mathrm{~m}$ & $\begin{array}{l}\text { Mild SIMP gyral pattern, moderate } \\
\text { myelination delay, hypogenesis of the CC } \\
\text { affecting the rostrum, and normal } \\
\text { cerebellum }\end{array}$ \\
\hline $\operatorname{Im} 11 / F$ & 1 y 7 mo & p.Gln86Profs*35 & No & - & - & 2 y 6 mo & $\begin{array}{l}\text { Moderate SIMP, mild myelination delay, } \\
\text { hypogenesis of the CC affecting the rostrum, } \\
\text { and normal cerebellum }\end{array}$ \\
\hline Im05/M & 10 y 2 mo & p.Gln86Profs*35 & Yes & $5 \mathrm{mo}$ & GTCS (1 each 6 mo) with LTG and CZP & 2 y 8 mo & $\begin{array}{l}\text { Moderate SIMP gyral with cortical atrophy, } \\
\text { severe myelination delay, hypogenesis of the } \\
\text { CC affecting the rostrum, and normal } \\
\text { cerebellum }\end{array}$ \\
\hline Nan02/F & $3 y$ & p.Gln86Aspfs*34 & Yes & 1 y 6 mo & $\begin{array}{l}2 \text { SE then GTS }(1 / m) \text { with AED with LTG, VPA, } \\
\text { CZP }\end{array}$ & $3 y$ & $\begin{array}{l}\text { Moderate SIMP with mild cortical atrophy, } \\
\text { severe myelination delay, complete agenesis } \\
\text { of the CC, and normal cerebellum }\end{array}$ \\
\hline Bay01/F & 7 y 5 mo & p.Gln86Argfs*106 & No & - & - & 3 y 2 mo & $\begin{array}{l}\text { Normal gyral pattern, mild myelination delay, } \\
\text { hypogenesis of the CC affecting the rostrum, } \\
\text { and normal cerebellum }\end{array}$ \\
\hline Mon01/M & $10 y$ & p.Gln86Argfs*106 & Yes & $1 \mathrm{y}$ & $\begin{array}{l}\text { IS then myoclonic seizures with } \\
\text { photosensitivity; seizure free from the age of } \\
4\end{array}$ & 3 y 6 mo & $\begin{array}{l}\text { Mild SIMP gyral pattern, severe cortical } \\
\text { atrophy, mild myelination delay, complete CC } \\
\text { agenesis, and normal cerebellum }\end{array}$ \\
\hline Rou01/M & $3 y$ & p.Glu136Glyfs*39 & Yes & 1 y 3 mo & $\begin{array}{l}\text { GTS and IS; } 1 \text { SE, drug-resistant multifocal } \\
\text { epilepsy with VGB and TPM }\end{array}$ & $34 \mathrm{mo}$ & $\begin{array}{l}\text { Pachygyria, severe myelination delay, } \\
\text { hypoplastic CC, and normal cerebellum }\end{array}$ \\
\hline Ren01/M & $12 y$ & p.Glu154Glyfs*301 & Yes & $6 y$ & 1 episode of FS then seizure free & 12 y 8 mo & $\begin{array}{l}\text { Mild SIMP gyral pattern with mild cortical } \\
\text { atrophy, normal myelination, hypogenesis of } \\
\text { the CC affecting the rostrum, and cerebellar } \\
\text { atrophy }\end{array}$ \\
\hline Leu01/F & $5 y$ & p.Glu154Glyfs*301 & No & - & - & $5 y$ & $\begin{array}{l}\text { Normal gyral pattern, mild myelination delay, } \\
\text { and normal CC and cerebellum }\end{array}$ \\
\hline Thi01/F & $9 y$ & p.Glu154Glyfs*301 & Yes & $2 y$ & GTS then seizure free & 9 y 3 mo & $\begin{array}{l}\text { Moderate SIMP with mild cortical atrophy, } \\
\text { mild myelination delay, complete agenesis of } \\
\text { the CC, and cerebellar atrophy }\end{array}$ \\
\hline Im06/F & 4 y $10 \mathrm{mo}$ & p.Glu154Glyfs*301 & No & - & - & 1 y $11 \mathrm{mo}$ & $\begin{array}{l}\text { Pachygyria, severe myelination delay, } \\
\text { hypogenesis of the CC with absence of } \\
\text { rostrum, and mild cerebellar atrophy }\end{array}$ \\
\hline
\end{tabular}




\begin{tabular}{|c|c|c|c|c|c|c|c|}
\hline Patient/sex & $\begin{array}{l}\text { Age at last } \\
\text { follow-up }\end{array}$ & Mutation & Epilepsy & $\begin{array}{l}\text { Age at } \\
\text { seizure onset }\end{array}$ & Seizure history & $\begin{array}{l}\text { Age at } \\
\text { MRI }\end{array}$ & MRI Pattern \\
\hline Im09/M & $6 y$ & p.Glu154Glyfs*301 & Yes & $4 y$ & Occasional GTCS (1/y) with VPA (normal EEG) & 3 y 3 mo & $\begin{array}{l}\text { Mild SIMP, mild myelination delay, } \\
\text { hypogenesis of the CC affecting the rostrum, } \\
\text { and normal cerebellum }\end{array}$ \\
\hline Ang02/M & $2 y$ & p.Glu154Glyfs*301 & Yes & $3 \mathrm{mo}$ & Focal motor seizures $(4 / \mathrm{mo})$ & 1 y 3 mo & $\begin{array}{l}\text { Mild SIMP gyral pattern with moderate } \\
\text { cortical atrophy, severe myelination delay, } \\
\text { hypogenesis of the CC affecting the rostrum, } \\
\text { and normal cerebellum }\end{array}$ \\
\hline Im04/F & $11 \mathrm{y}$ & p.Glu155Glyfs*300 & Yes & $4 \mathrm{mo}$ & $\begin{array}{l}\text { Myoclonic seizures treated with VPA, then } \\
\text { seizure free from the age of } 4 \mathrm{y}\end{array}$ & 1 y 10 mo & $\begin{array}{l}\text { Mild SIMP gyral pattern, severe myelination } \\
\text { delay, hypogenesis of the CC affecting the } \\
\text { rostrum, and normal cerebellum }\end{array}$ \\
\hline Tou01/M & ND & p.Glu155* & Yes & $10 \mathrm{mo}$ & $\begin{array}{l}\text { Drug-resistant multifocal epilepsy (Lennox } \\
\text { Gastaut like) }\end{array}$ & 2 y 6 mo & $\begin{array}{l}\text { Pachygyria, severe myelination delay, } \\
\text { hypoplastic CC, and normal cerebellum }\end{array}$ \\
\hline Im10/M & 4 y $12 \mathrm{mo}$ & p.Lys162Serfs*51 & Yes & $2 y$ & Occasional GTCS with VPA & $4 y$ & $\begin{array}{l}\text { Moderate SIMP gyral pattern with cortical } \\
\text { atrophy, severe myelination delay, partial } \\
\text { agenesis of the CC, and normal cerebellum }\end{array}$ \\
\hline$R d b 02 / M$ & $6 y$ & p.Tyr179* & Yes & $11 \mathrm{mo}$ & $\begin{array}{l}\text { Focal seizures, with secondary generalization } \\
\text { refractory }\end{array}$ & 2 y 3 mo & $\begin{array}{l}\text { Pachygyria with moderate cortical atrophy, } \\
\text { severe myelination delay, partial agenesis of } \\
\text { the CC, and normal cerebellum }\end{array}$ \\
\hline Im03/F & 2 y 4 mo & p.Ser185GInfs*270 & Yes & 1 y 5 mo & $\begin{array}{l}\text { Focal seizures, with secondary generalization } \\
\text { then seizure free with AED }\end{array}$ & $2 y$ & $\begin{array}{l}\text { Mild SIMP gyral pattern with mild cortical } \\
\text { atrophy, moderate myelination delay, } \\
\text { extremely hypoplastic CC, and normal } \\
\text { cerebellum }\end{array}$ \\
\hline Pit02/M & $22 \mathrm{y}$ & p.lle194Serfs*19 & Yes & $1 \mathrm{y}$ & GTS then seizure free & ND & $\begin{array}{l}\text { Mild SIMP gyral pattern, myelination delay, } \\
\text { hypoplastic CC with hypoplastic rostrum }\end{array}$ \\
\hline Ren03/M & $32 \mathrm{y}$ & p.Gln196* & Yes & $4 y$ & $\begin{array}{l}1 \mathrm{SE} \text { then occasional GTCS between } 4 \text { and } 10 \mathrm{y} \\
\text { then seizure free }\end{array}$ & $7 \mathrm{mo}$ & $\begin{array}{l}\text { Partial agenesis of the CC and normal } \\
\text { cerebellum }\end{array}$ \\
\hline Ade01/M & $7 y$ & p.Tyr208_lle211del & Yes & 1 y 8 mo & $\begin{array}{l}\text { Recurrent seizures }(3 / d) \text {, then seizure free } \\
\text { with AED }\end{array}$ & 2 y 7 mo & $\begin{array}{l}\text { Mild SIMP with mild cortical atrophy, absence } \\
\text { of myelination delay, hypogenesis of the CC } \\
\text { affecting the rostrum, and normal } \\
\text { cerebellum }\end{array}$ \\
\hline Str03/M & $20 y$ & p.Val242Cysfs*84 & Yes & $6 \mathrm{mo}$ & Myoclonic seizures and then GTCS & $8 \mathrm{mo}$ & $\begin{array}{l}\text { Pachygyria, moderate myelination delay, } \\
\text { hypoplastic CC, and normal cerebellum }\end{array}$ \\
\hline Im01/F & $10 y$ & p.Tyr254Thrfs*72 & Yes & $3 y$ & GTCS, FS, under 3 AED & 7 y 4 mo & $\begin{array}{l}\text { Moderate SIMP with cortical atrophy, mild } \\
\text { myelination delay, hypoplastic CC affecting } \\
\text { the rostrum, and normal cerebellum }\end{array}$ \\
\hline
\end{tabular}


Table 1 Individual data on epilepsy and MRI pattern on 45 patients with de novo FOXG1 mutations/deletions (continued)

\begin{tabular}{|c|c|c|c|c|c|c|c|}
\hline Patient/sex & $\begin{array}{l}\text { Age at last } \\
\text { follow-up }\end{array}$ & Mutation & Epilepsy & $\begin{array}{l}\text { Age at } \\
\text { seizure onset }\end{array}$ & Seizure history & $\begin{array}{l}\text { Age at } \\
\text { MRI }\end{array}$ & MRI Pattern \\
\hline Tel01/M & 3 y 6 mo & p.lle266Tyrfs*189 & No & - & FS once & $11 \mathrm{mo}$ & $\begin{array}{l}\text { Moderate SIMP, mild myelination delay, } \\
\text { hypoplastic CC, and normal cerebellum }\end{array}$ \\
\hline Ren02/F & $10 y$ & p.Pro182Leu & Yes & $9 \mathrm{mo}$ & Atypical absence, GTCS; drug resistant & $1 \mathrm{y}$ & $\begin{array}{l}\text { Pachygyria, moderate myelination delay, } \\
\text { hypoplastic CC affecting the rostrum, and } \\
\text { normal cerebellum }\end{array}$ \\
\hline$R d b 01 / M$ & $8 y$ & p.Asn187Asp & Yes & 1 y 6 mo & IS then multifocal drug-resistant epilepsy & $18 \mathrm{mo}$ & $\begin{array}{l}\text { Pachygyria, severe myelination delay, } \\
\text { hypoplastic CC affecting the rostrum, and } \\
\text { normal cerebellum }\end{array}$ \\
\hline Lau01/M & $2 y$ & p.Asn187Lys & Yes & $12 \mathrm{mo}$ & IS then multifocal drug-resistant epilepsy & 2 y 5 mo & $\begin{array}{l}\text { Moderate SIMP with cortical atrophy, severe } \\
\text { myelination delay, hypoplastic CC, and } \\
\text { normal cerebellum }\end{array}$ \\
\hline Im08/M & $22 \mathrm{mo}$ & p.Arg195Pro & Yes & $8 \mathrm{mo}$ & GTS (10/d every 6 mo) with VPA and CZP & 2 y 2 mo & $\begin{array}{l}\text { Moderate SIMP gyral pattern with moderate } \\
\text { cortical atrophy, moderate myelination delay, } \\
\text { hypoplastic CC, and normal cerebellum }\end{array}$ \\
\hline Pit01/F & $42 y$ & p.Leu204Phe & Yes & $8 y$ & GTCS then seizure free & $39 y$ & $\begin{array}{l}\text { Mild SIMP with mild cortical atrophy, mild } \\
\text { white matter loss, hypoplastic CC affecting } \\
\text { the rostrum, and cerebellar atrophy }\end{array}$ \\
\hline Mar01/F & $4 y$ & p.Phe215Leu & Yes & $10 y$ & GTCS, seizure free with VPA & $3 y$ & $\begin{array}{l}\text { Normal gyral pattern with mild cortical } \\
\text { atrophy, moderate myelination delay, } \\
\text { hypoplastic CC affecting the rostrum, and } \\
\text { normal cerebellum }\end{array}$ \\
\hline Im12/F & 2 y 7 mo & p.Gly224Ser & Yes & $6 \mathrm{mo}$ & IS then seizure free under LTG, CZP from $2 y$ & 2 y 6 mo & $\begin{array}{l}\text { Normal gyral pattern, mild myelination delay, } \\
\text { hypoplastic CC, and normal cerebellum }\end{array}$ \\
\hline Ang01/M & 2 y 4 mo & p.Arg230His & No & - & - & 1 y $11 \mathrm{mo}$ & $\begin{array}{l}\text { Pachygyria, moderate myelination delay, } \\
\text { hypoplastic CC affecting the rostrum and } \\
\text { normal cerebellum }\end{array}$ \\
\hline Str02/F & $9 y$ & p.Gly252Val & No & - & - & $19 \mathrm{mo}$ & $\begin{array}{l}\text { Pachygyria, severe myelination delay, } \\
\text { hypoplastic CC, and normal cerebellum }\end{array}$ \\
\hline Lyo01/M & $4 y$ & p.Trp255Arg & Yes & $1 \mathrm{y}$ & ND & 2 y 2 mo & $\begin{array}{l}\text { Mild SIMP gyral pattern, mild myelination } \\
\text { delay, CC hypogenesis, and normal } \\
\text { cerebellum }\end{array}$ \\
\hline Nan03/F & $17 y$ & p.Leu257Pro & No & - & - & $4 y$ & $\begin{array}{l}\text { Normal cortex; anterior part CC } \\
\text { nonmyelinated }\end{array}$ \\
\hline Nan01/F & 7 y 1 mo & p.Asn408Ile & Yes & $9 y$ & Atypical absences with VPA & $13 y$ & Normal \\
\hline
\end{tabular}


Table 1 Individual data on epilepsy and MRI pattern on 45 patients with de novo FOXG1 mutations/deletions (continued)

\begin{tabular}{|c|c|c|c|c|c|c|c|}
\hline Patient/sex & $\begin{array}{l}\text { Age at last } \\
\text { follow-up }\end{array}$ & Mutation & Epilepsy & $\begin{array}{l}\text { Age at } \\
\text { seizure onset }\end{array}$ & Seizure history & $\begin{array}{l}\text { Age at } \\
\text { MRI }\end{array}$ & MRI Pattern \\
\hline $\operatorname{Im02/M}$ & 4 y 9 mo & p.Ser326Glufs*129 & Yes & $1 \mathrm{y}$ & $\begin{array}{l}\text { IS treated with VGB and steroids, then seizure } \\
\text { free }\end{array}$ & 1 y 1 mo & $\begin{array}{l}\text { Moderate SIMP with mild cortical atrophy, } \\
\text { moderate myelination delay, hypogenesis of } \\
\text { the CC affecting the rostrum, and normal } \\
\text { cerebellum }\end{array}$ \\
\hline Cle01/F & $18 y$ & p.Tyr400* & No & - & - & 7 y 11 mo & Normal \\
\hline Dij01/F & 18 y 2 mo & c.-715delinsTACCAAAA & Yes & 1 y 6 mo & $\begin{array}{l}\text { GTCS then seizure free under VPA ( } 3 \text { ys); } \\
\text { currently no treatment ( } 11 \mathrm{y})\end{array}$ & 15 y 11 mo & $\begin{array}{l}\text { Mild SIMP gyral pattern with mild cortical } \\
\text { atrophy, absence of myelination delay, } \\
\text { hypogenesis of the CC affecting the rostrum, } \\
\text { and cerebellar atrophy }\end{array}$ \\
\hline Lyo02/F & 1 y 6 mo & del14q12 $(29,222,002-29,258,618)$ & Yes & 1 y 4 mo & IS, seizure free under VGB & $8 \mathrm{mo}$ & $\begin{array}{l}\text { Mild SIMP gyral pattern, mild myelination } \\
\text { delay, hypogenesis of the CC affecting the } \\
\text { rostrum, and normal cerebellum }\end{array}$ \\
\hline Lyo03/F & 3 y 9 mo & del14q12 $(26,415,516-29,677,148)$ & Yes & 1 y 3 mo & $\begin{array}{l}\text { GTS then seizure free during } 2 \mathrm{mo} \text {, drug } \\
\text { resistant (seizure frequency } 1 / \mathrm{w} \text { ) }\end{array}$ & $9 \mathrm{mo}$ & $\begin{array}{l}\text { Mild SIMP gyral pattern, moderate } \\
\text { myelination delay, hypogenesis of the CC } \\
\text { affecting the rostrum and the genu, and } \\
\text { normal cerebellum }\end{array}$ \\
\hline Im07/F & $2 y$ & del14q12q13.1 & No & - & - & $5 \mathrm{mo}$ & $\begin{array}{l}\text { Moderate SIMP gyral pattern, moderate } \\
\text { myelination delay, complete agenesis of the } \\
\text { CC, and normal cerebellum }\end{array}$ \\
\hline Aix01/M & $7 y$ & del14q12 $(18,798,641-19,484,013)$ & Yes & $2 \mathrm{~d}$ of life & $\mathrm{FS}(<1 / \mathrm{mo})$ & $2 y$ & $\begin{array}{l}\text { Mild SIMP gyral pattern with moderate } \\
\text { cortical atrophy, moderate myelination delay, } \\
\text { hypoplastic CC, and normal cerebellum }\end{array}$ \\
\hline
\end{tabular}

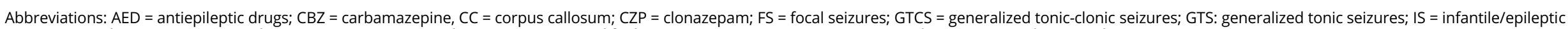
spasms; LEV = levetiracetam; LTG = lamotrigine; SE = status epilepticus; SIMP = simplified gyration; TPM = topiramate; VGB = vigabatrin; VPA = valproic acid. 


\section{Brain images}

Patients with FOXG1 syndrome showed a variable degree of gyration, moderate-to-severe myelination delay or white matter loss (64.4\%), and abnormal corpus callosum (95.6\%). From our detailed review of these imaging studies, we were able to delineate 3 groups of severity of gyration defect that are most easily appreciated with multiple views in several planes, as shown in figures 2, A-L and 3, A-H.

The first gyral pattern, the most severe, consisted of pachygyria, with thickened cortex with frontal lobe predominance $(12 / 45 ; 26.7 \%)$. This pattern was seen in the youngest patients (mean age 1.8 years) and was accentuated by the underdevelopment of the frontal lobes and the reduced volume of the subcortical white matter. In this group, myelination delay was prominent, ranging from severe $(7 / 11 ; 63.6 \%)$ to moderately delayed $(4 / 11 ; 36.4 \%)$. The most common corpus callosum anomaly was anterior hypogenesis, mostly affecting the genu and the rostrum $(6 / 11 ; 54.5 \%)$ (figure 2, A-L). Sequential MRI performed during the first years of life showed that this pachygyric appearance can be overestimated between the ages of 12 and 24 months because of the immature myelination (figure 3, A-H). Delayed myelination improved with age, and no case of hypomyelination or dysmyelination was observed after the age of 5 years.

The second gyral pattern of intermediate severity met the subjective criteria of moderately simplified gyral pattern. ${ }^{15}$ This pattern was observed in $24.4 \%$ (11/45) of patients with mean age of 3.1 years. In this group, myelination was moderately to severely delayed. The corpus callosum showed a wide range of anomalies, including complete agenesis $(5 / 11$; $45.5 \%)$, global hypoplasia $(3 / 11 ; 27.3 \%)$, and anterior hypogenesis $(3 / 11 ; 27.3 \%)$.

The third gyral pattern, the least severe, consisted of mildly simplified to normal gyral pattern. These patients (22/45; $48.9 \%$ ) were older than the 2 previous groups (mean age 6.1 years). White matter anomalies were mostly mild or absent $(14 / 22 ; 63.6 \%)$, and the corpus callosum was hypogenetic in its anterior part in the majority of cases $(14 / 22 ; 63.6 \%)$ (figure e-1 links.lww.com/NXG/A91).

Figure 2 Representative MRI of pachygyric frontal cortex in FOXG1 patients
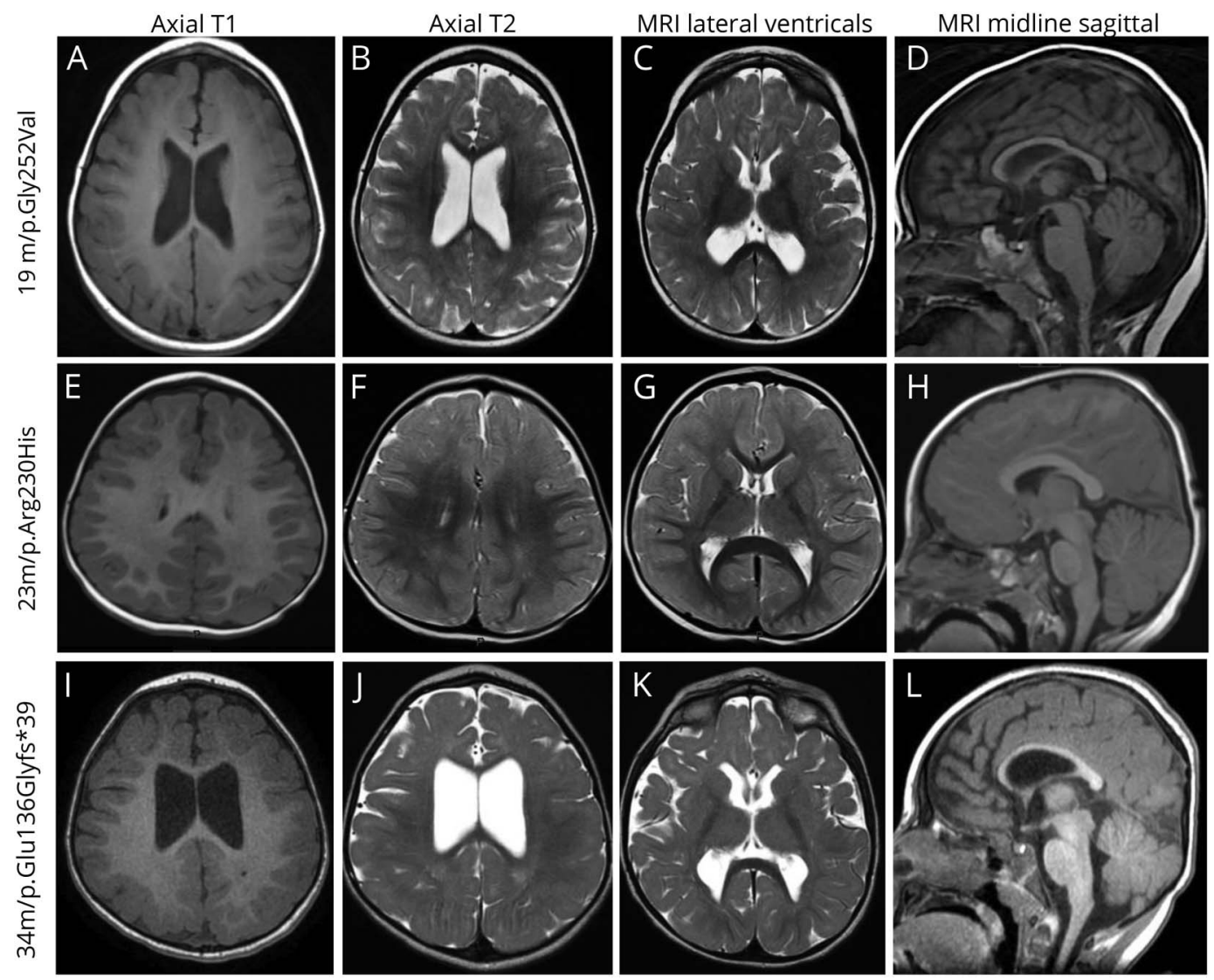

Representative images at the level of centrum semiovale in axial T1-weighted $(A, E, I)$ and T2-weighted (B, F, J) MRI, at the level of lateral ventricles (third column) and midline sagittal (right column). Each row shows images from the same patient respectively: (A-D) Str02 aged 19 months; (E-H) Ang01 aged 23 months; (I-L) Rou01, aged 34 months. The cortex appears mildly thick with a clear predominance in the frontal lobes. The appearance of pachygyria is accentuated by the underdevelopment of frontal lobes. T2-weighted (C, G, K) MRI at the level of the internal capsule showing associated myelination delay, with mature myelin only visible in both internal capsules ( $\mathrm{G}$ and $\mathrm{K}$ ). T1-weighted midline sagittal sections showing the wide range of appearance of the corpus callosum, from hypoplastic and thin $(D, L)$ to thick with underdevelopment of the genu $(H)$. 

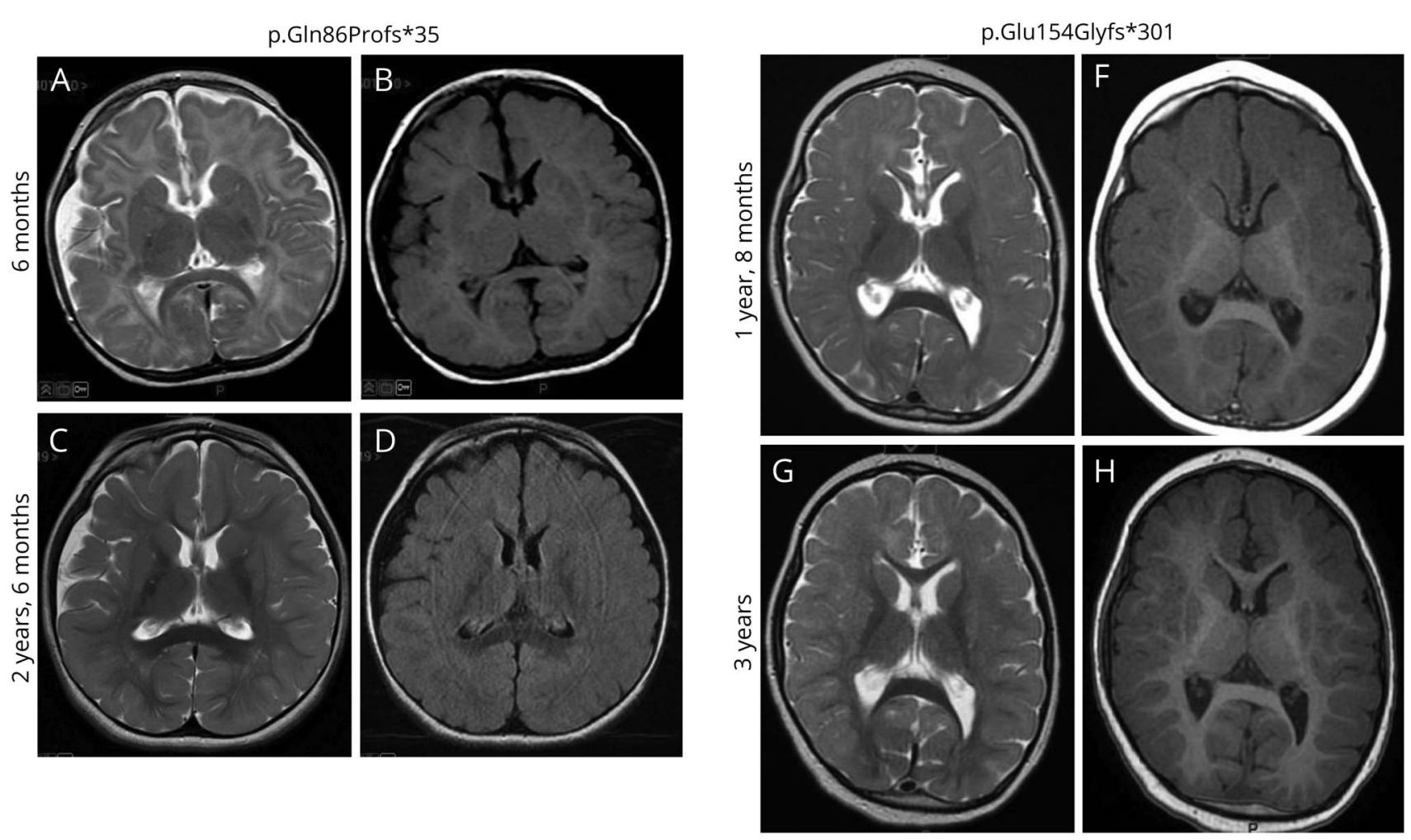

Representative images from 2 patients: Im11 p.GIn86Profs*35 (A-D) and Im09 p.Glu154Glyfs*301 (E-H). (A and B) Images obtained when the patient was 6 months old. T2-weighted image (A) shows normal thickness of both frontal lobes but delayed myelination. T1-weighted image (B) shows a pachygyric cortex in the same region. ( $C$ and D) Images obtained when the patient was 2 years 6 months. T2-weighted image (C) of the frontal lobe shows mildly thickened cortex, probably because of the poor myelination of the subcortical white matter. (E and F) Images obtained when the patient was 1 year 8 months. In the frontal lobe, T2-weighted (E) and T1-weighted (F) images show the same pattern of pachygyric cortex and severely delayed myelination (E). (G and H) At 3 years, the T2weighted image $(G)$ shows significant improvement of myelination, although still delayed in the frontal subcortical region: the T1-weighted image (H) shows mildly simplified gyral pattern, with no pachygyria.

\section{Genotype-phenotype relationships}

To assess genotype-phenotype associations in FOXG1 syndrome, we investigated the correlation between the score of selected FOXG1 criteria in the whole cohort and 5 genetic subgroups (e-results) (table 2).

Patients with $\mathrm{N}$-terminal mutations and FOXG1 deletions showed the highest global severity scores, while those with FBD frameshift and nonsense mutations showed the lowest global severity scores $(p<0.05)$. Patients with FBD missense and $\mathrm{C}$-terminal domain mutations tended to have lower global severity scores, although the differences were not significant because of the small size of these groups (figure e-2A links.lww. com/NXG/A92).

When covariance analysis was performed in the whole cohort, we found significant positive covariance of gyral and myelination pattern scores, suggesting that whatever the type of FOXG1 mutation, the most severe cortical anomaly (i.e., pachygyria) is correlated with the most severe myelination delay, further reinforcing the fact that this cortical anomaly may be overestimated because of the abnormal myelination of the subcortical fibers. Further analyses showed significant and distinct covariance relationships in which the MRI pattern appeared the most relevant criteria in distinguishing the genetic groups (figures e-3 links.lww.com/NXG/A93 and e-4 links.lww.com/ NXG/A94).

Interesting data also came from the analysis of patients with recurrent frameshift mutations c.460dupG and c.256dupC. Remarkably, among the patients with c.460dupG, we found significant differences in clinical and imaging presentations, demonstrating that genotype-phenotype correlation is not straightforward in FOXG1 syndrome. On MRI, this mutation resulted in a spectrum of corpus callosum anomalies, from complete agenesis to global hypoplasia (figure e-5 links.lww. com/NXG/A96). By contrast, the 3 patients with the $\mathrm{c}$. 256dupC had a more consistent phenotype.

\section{Discussion}

Foxg1 is a transcription factor that plays nonredundant roles in brain development, such that loss of a single copy of the gene severely affects brain formation, and knock-out mice cannot survive after birth. ${ }^{9,16}$ Consequently, it is not surprising that all mutations identified in humans are heterozygous and result in 
Table 2 Clinical and neuroimaging features related to the FOXG1 genotype groups

\begin{tabular}{|c|c|c|c|c|c|c|c|c|c|c|}
\hline \multirow[b]{2}{*}{ Cases number, $\mathbf{n}(\%)$} & \multicolumn{2}{|c|}{$\begin{array}{l}\mathrm{N} \text {-terminal } \\
\text { domain variants }\end{array}$} & \multicolumn{2}{|c|}{$\begin{array}{l}\text { Forkhead domain frameshift } \\
\text { and nonsense variants }\end{array}$} & \multicolumn{2}{|c|}{$\begin{array}{l}\text { Forkhead domain } \\
\text { missense variants }\end{array}$} & \multicolumn{2}{|c|}{$\begin{array}{l}\text { C-terminal domain } \\
\text { variants }\end{array}$} & \multicolumn{2}{|c|}{ Large deletions } \\
\hline & 19 & $39.5 \%$ & 6 & $13.3 \%$ & 12 & $25.60 \%$ & 3 & $7 \%$ & 5 & $11.6 \%$ \\
\hline Sex, M/F & $10 / 9$ & $52.6 \% / 47.4 \%$ & $4 / 2$ & $66.7 \% / 33.3 \%$ & $6 / 6$ & $50 \% / 50 \%$ & $1 / 2$ & $33.3 \% / 66.7 \%$ & $1 / 4$ & $20 \% / 80 \%$ \\
\hline Median age at last follow-up (y) & 4.8 & & 15 & & 5.5 & & 7.1 & & 3.8 & \\
\hline \multicolumn{11}{|l|}{ Pregnancy and neonatal period } \\
\hline Problems in pregnancy/scans & $0 / 17$ & $0 \%$ & $2 / 4$ & $50 \%$ & $4 / 11$ & $36.4 \%$ & $0 / 3$ & $0 \%$ & $2 / 5$ & $40 \%$ \\
\hline Mean gestation at delivery $(\mathrm{GW}) / \mathrm{n}$ & 39.7 & 18 & 38.2 & 6 & 39.1 & 11 & 39.2 & 3 & 38.9 & 5 \\
\hline Neonatal issues & $4 / 17$ & $23.7 \%$ & $1 / 4$ & $25 \%$ & $2 / 11$ & $18.20 \%$ & $1 / 3$ & $33.3 \%$ & $4 / 5$ & $80 \%$ \\
\hline Feeding difficulties at birth & $3 / 17$ & $17.6 \%$ & $1 / 4$ & $25 \%$ & $1 / 11$ & $9.1 \%$ & $1 / 3$ & $33.3 \%$ & $2 / 5$ & $40 \%$ \\
\hline \multicolumn{11}{|l|}{ Body measurements at birth } \\
\hline Length $<-2$ SD & $0 / 16$ & $0 \%$ & $0 / 5$ & $0 \%$ & $1 / 10$ & $10 \%$ & $0 / 3$ & $0 \%$ & $0 / 5$ & $0 \%$ \\
\hline Weight $<-2$ SD & $0 / 17$ & $0 \%$ & $0 / 5$ & $0 \%$ & $0 / 11$ & $0 \%$ & $0 / 3$ & $0 \%$ & $0 / 5$ & $0 \%$ \\
\hline$H C<-2 S D$ & $1 / 18$ & $5.6 \%$ & $0 / 5$ & $0 \%$ & $3 / 12$ & $25 \%$ & $0 / 3$ & $0 \%$ & $0 / 5$ & $0 \%$ \\
\hline
\end{tabular}

Body measurements at last evaluation

\begin{tabular}{|c|c|c|c|c|c|c|c|c|c|c|}
\hline Median age $(y) / n$ & 4.7 & 18 & 6.6 & 5 & 7.5 & 12 & 7.1 & 3 & 3.8 & 5 \\
\hline Height $<-2 S D$ & $1 / 14$ & $7.1 \%$ & $1 / 3$ & $33.3 \%$ & $3 / 9$ & $33.3 \%$ & $0 / 2$ & $0 \%$ & $2 / 5$ & $40 \%$ \\
\hline Weight $<-2 S D$ & $4 / 17$ & $23.5 \%$ & $1 / 3$ & $33.3 \%$ & $4 / 11$ & $36.4 \%$ & $1 / 3$ & $33.3 \%$ & $3 / 5$ & $60 \%$ \\
\hline$H C<-2 S D$ & $18 / 19$ & $94.7 \%$ & $5 / 5$ & $100 \%$ & $8 / 10$ & $80 \%$ & $3 / 3$ & $100 \%$ & $5 / 5$ & $100 \%$ \\
\hline $\mathrm{HC}<-4 \mathrm{SD}$ & $14 / 19$ & $73.7 \%$ & $3 / 5$ & $60 \%$ & $4 / 10$ & $40 \%$ & $1 / 3$ & $33.3 \%$ & $4 / 5$ & $80 \%$ \\
\hline
\end{tabular}

\section{Microcephaly score}

\begin{tabular}{|c|c|c|c|c|c|c|c|c|c|c|}
\hline $0=$ Normal at birth and at last evaluation & $1 / 18$ & $5.6 \%$ & $1 / 5$ & $20 \%$ & $2 / 11$ & $18.2 \%$ & $0 / 3$ & $0 \%$ & $0 / 5$ & $0 \%$ \\
\hline 1 = Postnatal microcephaly & $3 / 18$ & $16.7 \%$ & $1 / 5$ & $20 \%$ & $3 / 11$ & $27.3 \%$ & $2 / 3$ & $66.7 \%$ & $1 / 5$ & $20 \%$ \\
\hline $2=$ Severe postnatal microcephaly, -4 to -6 SD & $13 / 18$ & $72.2 \%$ & $3 / 5$ & $60 \%$ & $3 / 11$ & $27.3 \%$ & $1 / 3$ & $33.3 \%$ & $4 / 5$ & $80 \%$ \\
\hline $3=$ Congenital and postnatal microcephaly & $1 / 18$ & $5.7 \%$ & $0 / 5$ & $0 \%$ & $3 / 11$ & $27.3 \%$ & $0 / 3$ & $0 \%$ & $0 / 5$ & $0 \%$ \\
\hline
\end{tabular}


Table 2 Clinical and neuroimaging features related to the FOXG1 genotype groups (continued)

\begin{tabular}{|c|c|c|c|c|c|c|c|c|c|c|}
\hline Motor and speech development & \multicolumn{2}{|c|}{$\begin{array}{l}\mathrm{N} \text {-terminal } \\
\text { domain variants }\end{array}$} & \multicolumn{2}{|c|}{$\begin{array}{l}\text { Forkhead domain frameshift } \\
\text { and nonsense variants }\end{array}$} & \multicolumn{2}{|c|}{$\begin{array}{l}\text { Forkhead domain } \\
\text { missense variants }\end{array}$} & \multicolumn{2}{|c|}{$\begin{array}{l}\text { C-terminal domain } \\
\text { variants }\end{array}$} & \multicolumn{2}{|c|}{ Large deletions } \\
\hline Social interactions (eye contact and smiling intentionally) & $10 / 15$ & $66.7 \%$ & $3 / 3$ & $100 \%$ & $8 / 11$ & $72.7 \%$ & $3 / 3$ & $100 \%$ & $3 / 5$ & $60 \%$ \\
\hline Sit with support & $6 / 19$ & $31.6 \%$ & $2 / 6$ & $40 \%$ & $7 / 12$ & $58.3 \%$ & $2 / 3$ & $66.7 \%$ & $1 / 5$ & $20 \%$ \\
\hline Walked independently & $0 / 19$ & $0 \%$ & $0 / 6$ & $0 \%$ & $1 / 12$ & $8.3 \%$ & $2 / 3$ & $66.7 \%$ & $0 / 5$ & $0 \%$ \\
\hline Hand use & $10 / 19$ & $52.6 \%$ & $3 / 5$ & $60 \%$ & $4 / 12$ & $33.3 \%$ & $1 / 3$ & $33.3 \%$ & $1 / 5$ & $20 \%$ \\
\hline Speech (at least bisyllabisms) & $1 / 17$ & $5.9 \%$ & $0 / 6$ & $0 \%$ & $1 / 12$ & $8.3 \%$ & $1 / 3$ & $33.3 \%$ & $0 / 5$ & $0 \%$ \\
\hline \multicolumn{11}{|l|}{ Sleep and behavior disturbances } \\
\hline Inappropriate laughing/crying/screaming spells & 9/15 & $60 \%$ & $3 / 5$ & $60 \%$ & $7 / 12$ & $58.3 \%$ & $3 / 3$ & $100 \%$ & $2 / 5$ & $40 \%$ \\
\hline Impaired sleep pattern & $11 / 18$ & $61.1 \%$ & $4 / 5$ & $80 \%$ & $6 / 11$ & $54.5 \%$ & $2 / 3$ & $66.7 \%$ & $4 / 5$ & $80 \%$ \\
\hline Feeding difficulties & $13 / 19$ & $68.4 \%$ & $3 / 6$ & $50 \%$ & $9 / 12$ & $75 \%$ & $2 / 3$ & $66.7 \%$ & $5 / 5$ & $100 \%$ \\
\hline
\end{tabular}

\section{First concern and disease course}

Median age at first concerns (mo)/n

$\begin{array}{lll}3.7 & 18 & 3.5\end{array}$

\section{What were the first concerns?}

\begin{tabular}{|c|c|c|c|c|c|c|c|c|c|c|}
\hline Microcephaly & $7 / 19$ & $36.8 \%$ & $1 / 6$ & $50 \%$ & $4 / 12$ & $33.3 \%$ & $1 / 3$ & $33.3 \%$ & $2 / 5$ & $40 \%$ \\
\hline Strabismus/poor eye contact/abnormal ocular pursuit & $6 / 19$ & $31.6 \%$ & $2 / 6$ & $33.3 \%$ & $6 / 12$ & $50 \%$ & $0 / 3$ & $0 \%$ & $2 / 5$ & $40 \%$ \\
\hline Developmental Delay & $8 / 19$ & $42.1 \%$ & $4 / 6$ & $66.7 \%$ & $4 / 12$ & $33.3 \%$ & $2 / 3$ & $66.7 \%$ & $1 / 5$ & $20 \%$ \\
\hline Corpus callosum abnormalities & $0 / 18$ & $0 \%$ & $0 / 6$ & $0 \%$ & $1 / 12$ & $8.3 \%$ & $0 / 3$ & $0 \%$ & $2 / 5$ & $40 \%$ \\
\hline Seizures & $2 / 19$ & $10.5 \%$ & $0 / 6$ & $0 \%$ & $2 / 12$ & $16.7 \%$ & $0 / 3$ & $0 \%$ & $0 / 5$ & $0 \%$ \\
\hline Movement disorders & $2 / 19$ & $10.5 \%$ & $0 / 6$ & $0 \%$ & $2 / 12$ & $16.7 \%$ & $1 / 3$ & $33.3 \%$ & $1 / 5$ & $20 \%$ \\
\hline A period of regression & $3 / 19$ & $15.8 \%$ & $2 / 5$ & $40 \%$ & $2 / 12$ & $16.7 \%$ & $2 / 3$ & $66.7 \%$ & $1 / 5$ & $20 \%$ \\
\hline \multicolumn{11}{|l|}{ linical examination } \\
\hline Dysmorphic features & $8 / 18$ & $44.4 \%$ & $2 / 5$ & $40 \%$ & $3 / 11$ & $27.3 \%$ & $1 / 3$ & $33.3 \%$ & $1 / 5$ & $20 \%$ \\
\hline Axial hypotonia & $18 / 19$ & $94.7 \%$ & $5 / 6$ & $83.3 \%$ & $11 / 11$ & $100 \%$ & $3 / 3$ & $100 \%$ & $5 / 5$ & $100 \%$ \\
\hline Hypertonia/spasticity & 13/19 & $68.4 \%$ & $5 / 6$ & $83.3 \%$ & $8 / 12$ & $66.7 \%$ & $1 / 3$ & $33.3 \%$ & $3 / 5$ & $60 \%$ \\
\hline
\end{tabular}


Table 2 Clinical and neuroimaging features related to the FOXG1 genotype groups (continued)

\begin{tabular}{|c|c|c|c|c|c|c|c|c|c|c|}
\hline \multirow[b]{2}{*}{ Movement disorders } & \multicolumn{2}{|c|}{$\begin{array}{l}\text { N-terminal } \\
\text { domain variants }\end{array}$} & \multicolumn{2}{|c|}{$\begin{array}{l}\text { Forkhead domain frameshift } \\
\text { and nonsense variants }\end{array}$} & \multicolumn{2}{|c|}{$\begin{array}{l}\text { Forkhead domain } \\
\text { missense variants }\end{array}$} & \multicolumn{2}{|c|}{$\begin{array}{l}\text { C-terminal domain } \\
\text { variants }\end{array}$} & \multicolumn{2}{|c|}{ Large deletions } \\
\hline & $19 / 19$ & $100 \%$ & $6 / 6$ & $100 \%$ & $12 / 12$ & $100 \%$ & $3 / 3$ & $100 \%$ & $5 / 5$ & $100 \%$ \\
\hline Stereotypic movements & $15 / 19$ & $78.9 \%$ & $3 / 4$ & $75 \%$ & $8 / 12$ & $63.6 \%$ & $3 / 3$ & $100 \%$ & $5 / 5$ & $100 \%$ \\
\hline Strabismus & $16 / 18$ & $88.9 \%$ & $4 / 4$ & $100 \%$ & $10 / 12$ & $81.8 \%$ & $3 / 3$ & $100 \%$ & $5 / 5$ & $100 \%$ \\
\hline Scoliosis & $5 / 19$ & $26.3 \%$ & $1 / 5$ & $20 \%$ & $1 / 11$ & $9.1 \%$ & $1 / 3$ & $33.3 \%$ & $1 / 5$ & $20 \%$ \\
\hline \multicolumn{11}{|l|}{ Epilepsy } \\
\hline Seizure occurrence & $15 / 19$ & $78.9 \%$ & $5 / 6$ & $80 \%$ & $9 / 12$ & $75 \%$ & $2 / 3$ & $66.7 \%$ & $4 / 5$ & $80 \%$ \\
\hline Median age at seizure onset (y) & 1 & & 1.4 & & 1 & & 5 & & 1.3 & \\
\hline
\end{tabular}

Severity of epilepsy

\begin{tabular}{|c|c|c|c|c|c|c|c|c|c|c|}
\hline $0=$ No seizures & $4 / 19$ & $21 \%$ & $1 / 6$ & $16.7 \%$ & $3 / 12$ & $25 \%$ & $1 / 3$ & $33.3 \%$ & $1 / 5$ & $20 \%$ \\
\hline $1=$ Seizure onset $>2 y$ and seizure free after withdrawal AE & $2 / 15$ & $13.3 \%$ & $1 / 5$ & $16.7 \%$ & $1 / 9$ & $11.1 \%$ & $0 / 2$ & $0 \%$ & $0 / 4$ & $0 \%$ \\
\hline $2=$ Seizure onset $>2 y$ and seizure free with $A E$ & $2 / 15$ & $13.3 \%$ & $2 / 5$ & $40 \%$ & $2 / 9$ & $22.2 \%$ & $0 / 2$ & $0 \%$ & $1 / 4$ & $25 \%$ \\
\hline $3=$ Seizure onset $<2 y$ and continuing seizures with $\mathrm{AE}$ & $6 / 15$ & $40 \%$ & $2 / 5$ & $40 \%$ & $3 / 9$ & $33.3 \%$ & $1 / 2$ & $50 \%$ & $1 / 4$ & $25 \%$ \\
\hline 4 = Severe infantile spasms or seizure onset $<6 \mathrm{mo}$ & $5 / 15$ & $33.3 \%$ & $0 / 5$ & $0 \%$ & $3 / 9$ & $33.3 \%$ & $1 / 2$ & $50 \%$ & $2 / 4$ & $50 \%$ \\
\hline
\end{tabular}

3.4

2.3

5.6

7.9

3.95

Cortical anomalies

\begin{tabular}{|c|c|c|c|c|c|c|c|c|c|c|}
\hline Normal or mild SIMP gyral pattern & $8 / 19$ & $41.7 \%$ & $2 / 5$ & $40 \%$ & $5 / 11$ & $45.5 \%$ & $2 / 3$ & $66.7 \%$ & $4 / 5$ & $80 \%$ \\
\hline Moderate SIMP gyral pattern & $5 / 19$ & $26.3 \%$ & $2 / 5$ & $40 \%$ & $2 / 11$ & $18.2 \%$ & $1 / 3$ & $33.3 \%$ & $1 / 5$ & $20 \%$ \\
\hline Severe and pseudopachygyric cortex & $6 / 19$ & $31.6 \%$ & $1 / 5$ & $20 \%$ & $4 / 11$ & $36.4 \%$ & $0 / 3$ & $0 \%$ & $0 / 5$ & $0 \%$ \\
\hline Cortical atrophy & $12 / 19$ & $63.2 \%$ & $3 / 4$ & $75 \%$ & $7 / 11$ & $63.6 \%$ & $1 / 3$ & $33.3 \%$ & $2 / 5$ & $20 \%$ \\
\hline
\end{tabular}

Myelination delay

Absent to mild myelination delay

$6 / 19 \quad 31.6 \%$

2

Moderate myelination delay

$2 / 19 \quad 10.5 \%$

Severe myelination delay or white matter loss

$11 / 19$

$57.9 \%$

$2 / 4 \quad 50 \%$

$30 \%$

$0 \%$

$2 / 3 \quad 66.7 \%$

\begin{tabular}{lll}
\hline $.7 \%$ & $2 / 5$ & $40 \%$ \\
\hline $3.3 \%$ & $3 / 5$ & $60 \%$ \\
\hline 0 & $0 / 5$ & $0 \%$ \\
\hline & & Continued
\end{tabular}


noticeable changes in brain size and mental development early in childhood. To date, FOXG1 has been linked to a wide range of human congenital brain disorders. ${ }^{17,17-19}$ In this study, we describe detailed clinical and neuroradiological data on 45 patients with pathogenic single nucleotide variants and copy number variations affecting FOXG1. This is one of the largest cohort of patients with FOXG1 syndrome and focuses on FOXG1 point mutations, which affect both sexes equally. The aim of this study was to refine the phenotypic spectrum of FOXG1 syndrome and its natural history and to further investigate genotype-phenotype correlations. In keeping with previously published FOXG1-associated clinical features, we found FOXG1 syndrome to be associated with severe postnatal microcephaly ( -4 to $-6 \mathrm{SD})$, dyskinetic-hyperkinetic movement disorders, visual impairment, epilepsy, stereotypies, abnormal sleep patterns, and unexplained episodes of crying. $1,3,5-8,18,20-23$

Our data clearly confirm that head circumference is usually normal to borderline small at birth and evolves during infancy to severe microcephaly below $-3 \mathrm{SD}$, with normal somatic growth. Although no longitudinal data on head circumference are available from our series, it is interesting to note that microcephaly was the first concern in one-third of the cohort at the mean age of 3.47 months, suggesting that the slowdown in head growth occurs earlier than previously described. Of note, FOXG1-related postnatal microcephaly is characterized by underdevelopment of the frontal lobes, a unique pattern that does not occur in other causes of progressive microcephaly. ${ }^{24}$ This underdevelopment of frontal lobes can be associated with a mildly to moderately simplified gyral pattern and reduced white matter or in the youngest patients with a pachygyric appearance. We observed this pattern on T2weighted images in infants who showed mild gyral simplification later in childhood. The clue to the cause of the 2 patterns came from studying serial MRI of patients Im09 and $\operatorname{Im} 11$. Frontal pachygyria, which was observed at 6 months of age, changed into mild gyral simplification at 2.5 years of age. This finding suggested that the 2 cortical patterns did not represent differences of morphology but instead, differences in the maturity of the subcortical white matter. It is noteworthy that this changing appearance has been observed previously in polymicrogyria. 25,26

Another imaging hallmark of FOXG1 disorder is the delayed myelination. While delayed myelination has a similar appearance to hypomyelination on a single MRI, especially if done at an early age, sequential studies can distinguish between them by demonstrating increasing myelin content in delayed myelination. ${ }^{27}$ This evolution of delayed myelination toward normalization in childhood is not specific to FOXG1 syndrome, as it has been observed in other developmental disorders, such as MCT8 deficiency and Xq28 duplication involving MECP2 or SPTAN1 encephalopathy. ${ }^{27-29}$

Taken together with the published literature, we suggest that FOXG1 syndrome is a disorder in which hypogenetic corpus callosum is the most frequent finding. More specifically, corpus 
callosum malformations in FOXG1 syndrome are frontal predominant, similar to the gyral abnormality, suggesting that the same pathogenic mechanism operates for both the frontal cortical abnormalities and the callosal abnormalities. Complete agenesis occurs occasionally and is likely to represent the most severe end of the spectrum of pathogenic mechanisms underlying hypoplasia. This also illustrates that hypoplasia and agenesis are related to a similar mechanism and that genetic modifiers influence the severity of the callosal phenotype. ${ }^{30} \mathrm{Of}$ interest, the severity of corpus callosum anomaly does not correlate with the degree of microcephaly, the degree of myelination abnormality, or the degree of gyral abnormalities. This contrasts with data from congenital microcephaly that showed a correlation between the degree of microcephaly and the severity of the associated callosal anomaly. ${ }^{31}$

Hyperkinetic movement disorders have been recognized to be a key feature in FOXG1 syndrome since its original description. $^{6,18}$ Our data show that movement disorder is rarely the presenting feature of FOXG1 syndrome; this has not been stressed previously. It is important that the combination of hand stereotypes, mostly hand to mouth, with generalized dyskinesia is one of the key characteristics of FOXG1 syndrome that distinguishes it from other monogenic hyperkinetic movement disorders or neurodegenerative diseases. ${ }^{6,32}$ The hyperkinetic movement disorder, although affecting quality of life, was stable over time, never evolved into status dystonicus, and did not lead to any of the complications of severe dystonia that can observed in other developmental or degenerative neurologic disorders. ${ }^{6,32}$

A previous report suggested that FOXG1 syndrome could be classified as an epileptic-dyskinetic encephalopathy ${ }^{18}$ like $A R X$ - and STXBP1-related encephalopathies. Our data show that epilepsy is not a consistent feature, unlike dyskinetichyperkinetic movements. Although epilepsy affected $79 \%$ of patients reported here, which is within the range of previous reports (from $57 \%^{7}$ to $86 \%^{5}$ ), it did not show a particular seizure pattern that could help the clinician to define a specific epilepsy syndrome.

Since the first report that FOXG1 mutations can be responsible for congenital Rett variant, a number of publications have emphasized the differences between these disorders. ${ }^{33}$ Here, by applying the congenital Rett variant criteria, ${ }^{14}$ we confirm that the majority of patients with the FOXG1 syndrome do not meet the criteria for congenital Rett variant. At all ages, FOXG1 syndrome is more severe with respect to ambulation, reciprocity, and receptive language and has more disordered sleep, compared with Rett syndrome, as well as lacking the regression observed in Rett syndrome. These findings further reinforce that FOXG1 disorder is clinically separable from Rett syndrome, with distinct clinical presentation and natural history. It is important that patients with FOXG1 disorder receive appropriate counseling about medical comorbidities and natural history related to their disorder, avoiding the confusion with Rett syndrome.
The number of reported FOXG1 mutations is now large enough to search for genotype-phenotype correlations in FOXG1 syndrome. We observed that patients carrying mutations in the N-terminal domain and large deletion of FOXG1, which are the most common mutation types, show the most severe presentation and MRI anomalies, while those carrying mutations in the FBD or C-terminal domain were less severely affected. In previous series, a milder phenotype was observed in patients with missense variants in the FBD conserved site. However, the differences were found in items related to sitting, walking, and functional hand use, which are commonly severely impaired in all FOXG1 mutation patients. ${ }^{7}$ Using covariance and cluster analyses, we highlighted relationships between gyral and myelination patterns in patients with FOXG1 disorder. However, identical hotspot mutations c.256dupC and c.406dupG can be associated with highly variable features, such as variable epilepsy severity or degree of corpus callosum anomalies, underlining the importance of being cautious about predicting phenotype on the basis of genotype in the context of genetic counseling. This suggests that factors beyond the primary mutation can influence disease severity, including genetic modifiers and epigenetic and environmental factors.

The complexity and the poor reproducibility of genotypephenotype relationships in FOXG1 syndrome probably reflects the pleiotropic and nonredundant roles of Foxg1 in vertebrate brain development.

This study, one of the largest to date, provides evidence that FOXG1 mutations are responsible for a specific and recognizable neurodevelopmental disorder with a high degree of variability. We have expanded the phenotypic spectrum by defining 3 key brain imaging features of FOXG1 syndrome, noting that the degree of cortical abnormality is not correlated with the severity of the corpus callosum malformation. Moreover, our data confirm that mutations leading to the loss of the FBD domain, lead to the most severe clinical presentation of FOXG1 syndrome. The pathophysiology of such complex genotypephenotype relationships reflects the pleiotropic and nonredundant roles of Foxg1 during development.

\section{Affiliation}

From the Imagine Institute (N.V., M.C., C. Maillard, A.B., N.B.-B.), INSERM UMR 1163, Paris Descartes University, Necker Enfants Malades Hospital, Paris, France; Pediatric Neurology APHP — Necker Enfants Malades Hospital (M.C., M.H., N.B.-B.), Paris, France; Pediatric Radiology (N.B.), APHP_Necker Enfants Malades Hospital, Paris, France; Image-Imagine Institute (N.B.), INSERM UMR 1163, Paris Descartes University, Necker Enfants Malades Hospital, Paris, France; Department of Paediatric Clinical Epileptology (J.T.), Sleep Disorders and Functional Neurology, University Hospitals of Lyon (HCL), France; Service de Génétique médicale (E.S.), Hôpitaux Universitaires de Strasbourg, IGMA, France; Pediatric Neurology (T.L.-S.), Wolfson Medical Center, Tel Aviv, Israël; Wolfson Molecular Genetics Laboratory (D.L.), Wolfson Medical Center, Tel Aviv, Israël; Neurometabolism 
Department (B.M.), Angers Hospital and University, France; Centre de Génétique et Centre de Référence Maladies Rares Anomalies du Développement (S.M., A.M.), CHU Dijon, France; South Australian Clinical Genetics Service (E.H.), SA Pathology (at Royal Adelaide Hospital), and School of Medicine, University of Adelaide, Australia; Service de Génétique Médicale (B.I., M.N., M.V., B.C.), CHU Nantes, France; Département de Génétique et Centre de Référence Déficiences Intellectuelles de Causes Rares (D.H., C. Mignot), Hôpital de la Pitié-Salpêtrière, APHP, Paris, France; GMGF (M.M.), INSERM UMR_S910, Aix-Marseille University, Pediatric Neurology Unit, Timone Children Hospital, Marseille, France; Department of Neonatal Medicine (S.R.), Rouen University Hospital, Haute-Normandie, France; Department of Medical Genetics (C. Michot), Reference Center for Skeletal Dysplasia, INSERM UMR 1163, Laboratory of Molecular and Physiopathological Bases of Osteochondrodysplasia, Paris Descartes-Sorbonne Paris Cité University, AP-HP, Institut Imagine, and Hôpital Universitaire Necker-Enfants Malades, Paris, France; APHP (S.V.), GHUEP, Hôpital Trousseau, Neurologie Pédiatrique, Paris, France; GRC ConCer-LD (S.V.), Sorbonne Universités, UPMC Univ 06, Paris, France; Hôpital Nord Franche Comte (S.W.), CH HNFC-Site de Belfort, France; Pediatrics (A.D.), University of Basel Childrens' Hospital, Switzerland; CHU Rennes (S.O.), Service de Génétique Clinique, CNRS UMR6290, Université Rennes1, France; Service de Pédiatrie (L.L.), Centre Hospitalier de la Côte Basque, Bayonne, France; Department of Genetics (G.A.M.), Rouen University Hospital, France; Service de Génétique (A.S.), Hôpital Bretonneau, Tours, France; Service de Neurologie Pédiatrique (J.M.P.), Hôpital Pellegrin-Enfants, CHU de Bordeaux, France; Pédiatrie générale (I.C.), Hôpital de Lorient, France; Génétique Médicale-CHU Estaing CLERMONT-FERRAND (B.P., B.T.), France; Service de Neurologie Pédiatrique (F.R.), Hôpital Gui de Chauliac, CHRU de Montpellier, France; Equipe Génétique des Anomalies du Développement (C.P.), INSERM UMR1231, Université de Bourgogne-Franche Comté, Dijon, France; Laboratoire de Génétique chromosomique moléculaire (C.P.), Plateau technique de Biologie, CHU, Dijon, France; Laboratory of Biochemistry and Molecular Genetics (T.B.), HUPC Paris Centre, Cochin Hospital, Paris, France; National Rare Disease Center-Centre de Référence "déficiences intellectuelles de causes rares" (M.-A.S.), Strasbourg University Hospital, France; and National Rare Disease Center-Centre de Référence "déficiences intellectuelles de causes rares" (N.B.-B.), AP-HP, Necker Enfants Malades, Paris, France.

\section{Author contributions}

N. Vegas, M. Cavallin, C. Maillard: study concept and design, analysis and acquisition of clinical and molecular data. $\mathrm{N}$. Boddaert: analysis and acquisition of MRI data. J. Toulouse, E. Schaefer, T. Lerman-Sagie, D. Lev, B. Magalie, S. Moutton, E. Haan, B. Isidor, D. Heron, M. Milh, S. Rondeau, C. Michot, S. Valence, S. Wagner, M. Hully, C. Mignot, A. Masurel, A. Datta, S. Odent, M. Nizon, L. Lazaro, M. Vincent, B. Cogné,
G.A. Marie, A. Stéphanie, J.M. Pedespan, I. Caubel, B. Pontier, B. Troude, F. Rivier, M.-A. Spitz: acquisition of data and follow-up of the patients. C. Philippe and T. Bienvenu: analysis molecular data. A. Bery and N. Bahi-Buisson: study supervision, concept and critical revision of manuscript for intellectual content.

\section{Acknowledgment}

The authors would like to thank the affected individuals and their families for participation in this study, as well as the clinicians in charge of these patients who may not be cited. The authors would like to sincerely thank Prof Alessandra Pierani for her critical reading of the manuscript and helpful comments on our findings.

\section{Study funding}

Research reported in this publication was supported by the Agence Nationale de la Recherche (ANR-16-CE16-0011 MC, $\mathrm{AB}, \mathrm{NBB}$ ), the Fondation Maladies Rares, and DESIRE (grant agreement 602531). The project was also supported by the European Network on Brain Malformations (COST Action CA16118). The authors have no conflict of interest to declare.

\section{Disclosure}

N. Vegas, M. Cavallin, C. Maillard, N. Boddaert, J. Toulouse, E. Schaefer report no disclosures. T. Lerman-Sagie has served on the editorial boards of the Journal of Child Neurology, Harefuah, and the European Journal of Paediatric Neurology. D. Lev has received research support from the Sackler School of Medicine (Tel Aviv University). M. Barth and S. Moutton report no disclosures. E. Haan has received research support from the Lipedema Foundation (USA). B. Isidor and D. Heron report no disclosures. M. Milh has received speaker honoraria from Shire and Cyberonics. S. Rondeau, C. Michot, S. Valence, S. Wagner, M. Hully, C. Mignot, A. Masurel, A. Datta, S. Odent, M. Nizon, L. Lazaro, M. Vincent, B. Cogné, A.M. Guerrot, S. Arpin, J.M. Pedespan, I. Caubel, B. Pontier, B. Troude, F. Rivier, C. Philippe, T. Bienvenu, M. Spitz, and A. Bery report no disclosures. N. Bahi-Buisson has received research support from Agence Nationale de la recherche, Fondation pour la Recherche Médicale, Fondation NRJInstitut de France, and the EU-FP7 project GENECODYS. Full disclosure form information provided by the authors is available with the full text of this article at Neurology.org/NG.

Received March 24, 2018. Accepted in final form July 12, 2018.

\section{References}

1. Ariani F, Hayek G, Rondinella D, et al. FOXG1 is responsible for the congenital variant of Rett syndrome. Am J Hum Genet 2008;83:89-93.

2. Mencarelli MA, Spanhol-Rosseto A, Artuso R, et al. Novel FOXG1 mutations associated with the congenital variant of Rett syndrome. J Med Genet 2010;47:49-53.

3. Kortum F, Das S, Flindt M, et al. The core FOXG1 syndrome phenotype consists of postnatal microcephaly, severe mental retardation, absent language, dyskinesia, and corpus callosum hypogenesis. J Med Genet 2011;48:396-406.

4. Ellaway CJ, Ho G, Bettella E, et al. 14q12 Microdeletions excluding FOXG1 give rise to a congenital variant Rett syndrome-like phenotype. Eur J Hum Genet 2013;21: $522-527$.

5. Seltzer LE, Ma M, Ahmed S, et al. Epilepsy and outcome in FOXG1-related disorders. Epilepsia 2014;55:1292-1300.

6. Papandreou A, Schneider RB, Augustine EF, et al. Delineation of the movement disorders associated with FOXG1 mutations. Neurology 2016;86:1794-1800. 
7. Mitter D, Pringsheim M, Kaulisch M, et al. FOXG1 syndrome: genotype-phenotype association in 83 patients with FOXG1 variants. Genet Med 2018;20:98-108.

8. Bahi-Buisson N, Nectoux J, Girard B, et al. Revisiting the phenotype associated with FOXG1 mutations: two novel cases of congenital Rett variant. Neurogenetics 2010; 11:241-249.

9. Kumamoto T, Hanashima C. Evolutionary conservation and conversion of Foxg1 function in brain development. Dev Growth Differ 2017;59:258-269.

10. Krishnaraj R, Ho G, Christodoulou J. RettBASE: Rett syndrome database update. Hum Mutat 2017;38:922-931.

11. Le Guen T, Bahi-Buisson N, Nectoux J, et al. A FOXG1 mutation in a boy with congenital variant of Rett syndrome. Neurogenetics 2011;12:1-8.

12. Diebold B, Delepine C, Nectoux J, Bahi-Buisson N, Parent P, Bienvenu T. Somatic mosaicism for a FOXG1 mutation: diagnostic implication. Clin Genet 2014;85:589-591.

13. Sanger TD, Chen D, Fehlings DL, et al. Definition and classification of hyperkinetic movements in childhood. Mov Disord 2010;25:1538-1549.

14. Neul JL, Kaufmann WE, Glaze DG, et al. Rett syndrome: revised diagnostic criteria and nomenclature. Ann Neurol 2010;68:944-950.

15. Adachi Y, Poduri A, Kawaguch A, et al. Congenital microcephaly with a simplified gyral pattern: associated findings and their significance. AJNR Am J Neuroradiol 2011;32:1123-1129.

16. Xuan S, Baptista CA, Balas G, Tao W, Soares VC, Lai E. Winged helix transcription factor BF-1 is essential for the development of the cerebral hemispheres. Neuron 1995; 14:1141-1152.

17. Striano P, Paravidino R, Sicca F, et al. West syndrome associated with $14 \mathrm{q} 12$ duplications harboring FOXG1. Neurology 2011;76:1600-1602.

18. Cellini E, Vignoli A, Pisano T, et al. The hyperkinetic movement disorder of FOXG1related epileptic-dyskinetic encephalopathy. Dev Med Child Neurol 2016;58:93-97.

19. Mariani J, Coppola G, Zhang P, et al. FOXG1-dependent dysregulation of GABA/ glutamate neuron differentiation in autism spectrum disorders. Cell 2015;162:375-390.

20. De Bruyn C, Vanderhasselt T, Tanyalcin I, et al. Thin genu of the corpus callosum points to mutation in FOXG1 in a child with acquired microcephaly, trigonocephaly, and intellectual developmental disorder: a case report and review of literature. Eur J Paediatr Neurol 2014;18:420-426.
21. De Filippis R, Pancrazi L, Bjorgo K, et al. Expanding the phenotype associated with FOXG1 mutations and in vivo FoxG1 chromatin-binding dynamics. Clin Genet 2012; 82:395-403.

22. Florian C, Bahi-Buisson N, Bienvenu T. FOXG1-Related disorders: from clinical description to molecular genetics. Mol Syndromol 2012;2:153-163.

23. Van der Aa N, Van den Bergh M, Ponomarenko N, Verstraete L, Ceulemans B, Storm $\mathrm{K}$. Analysis of FOXG1 is highly recommended in male and female patients with Rett syndrome. Mol Syndromol 2011;1:290-293.

24. Seltzer LE, Paciorkowski AR. Genetic disorders associated with postnatal microcephaly. Am J Med Genet C Semin Med Genet 2014;166C:140-155.

25. Takanashi J, Barkovich AJ. The changing MR imaging appearance of polymicrogyria: a consequence of myelination. AJNR Am J Neuroradiol 2003;24:788-793.

26. Bahi-Buisson N, Poirier K, Boddaert N, et al. GPR56-related bilateral frontoparietal polymicrogyria: further evidence for an overlap with the cobblestone complex. Brain 2010;133:3194-3209.

27. van der Knaap MS, Wolf NI. Hypomyelination versus delayed myelination. Ann Neurol 2010;68:115.

28. El Chehadeh S, Faivre L, Mosca-Boidron AL, et al. Large national series of patients with Xq28 duplication involving MECP2: delineation of brain MRI abnormalities in 30 affected patients. Am J Med Genet A 2016;170A:116-129.

29. Syrbe S, Harms FL, Parrini E, et al. Delineating SPTAN1 associated phenotypes: from isolated epilepsy to encephalopathy with progressive brain atrophy. Brain 2017;140: 2322-2336.

30. Edwards TJ, Sherr EH, Barkovich AJ, Richards LJ. Clinical, genetic and imaging findings identify new causes for corpus callosum development syndromes. Brain 2014; 137:1579-1613

31. Barkovich AJ, Kjos BO. Normal postnatal development of the corpus callosum as demonstrated by MR imaging. AJNR Am J Neuroradiol 1988;9:487-491.

32. Carecchio M, Mencacci NE. Emerging monogenic complex hyperkinetic disorders. Curr Neurol Neurosci Rep 2017;17:97.

33. Ma M, Adams HR, Seltzer LE, Dobyns WB, Paciorkowski AR. Phenotype differentiation of FOXG1 and MECP2 disorders: a new method for characterization of developmental encephalopathies. J Pediatr 2016;178:233-240 e210. 


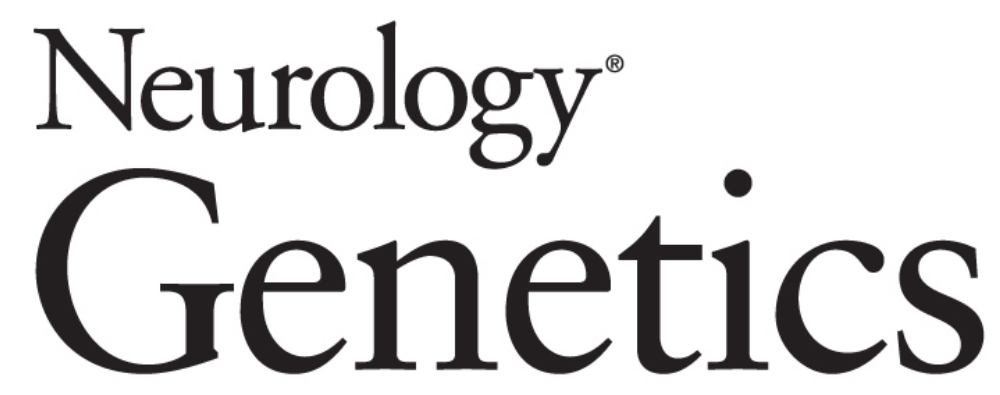

\section{Delineating FOXG1 syndrome: From congenital microcephaly to hyperkinetic encephalopathy \\ Nancy Vegas, Mara Cavallin, Camille Maillard, et al. Neurol Genet 2018;4; \\ DOI 10.1212/NXG.0000000000000281}

This information is current as of November 7, 2018

\section{Updated Information \& Services}

References

Citations

Subspecialty Collections

Permissions \& Licensing

Reprints including high resolution figures, can be found at: http://ng.neurology.org/content/4/6/e281.full.html

This article cites 33 articles, 4 of which you can access for free at: http://ng.neurology.org/content/4/6/e281.full.html\#\#ref-list-1

This article has been cited by 6 HighWire-hosted articles: http://ng.neurology.org/content/4/6/e281.full.html\#\#otherarticles

This article, along with others on similar topics, appears in the following collection(s):

MRI

http://ng.neurology.org//cgi/collection/mri

Rett Syndrome

http://ng.neurology.org//cgi/collection/rett_syndrome

Information about reproducing this article in parts (figures,tables) or in its entirety can be found online at:

http://ng.neurology.org/misc/about.xhtml\#permissions

Information about ordering reprints can be found online: http://ng.neurology.org/misc/addir.xhtml\#reprintsus

Neurol Genet is an official journal of the American Academy of Neurology. Published since April 2015, it is an open-access, online-only, continuous publication journal. Copyright Copyright $(2018$ The Author(s). Published by Wolters Kluwer Health, Inc. on behalf of the American Academy of Neurology.. All rights reserved. Online ISSN: 2376-7839.

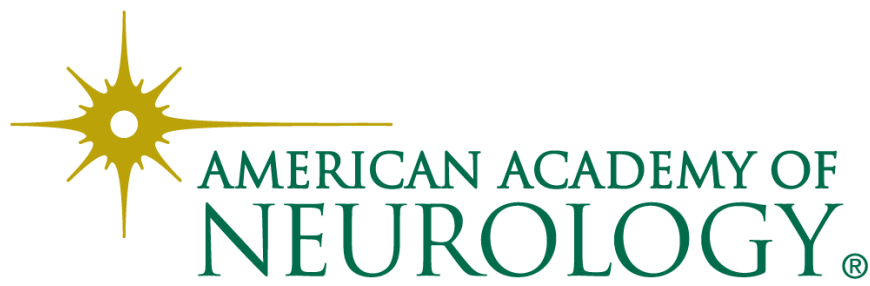

